\title{
GGE BIPLOT ANALYSIS OF YIELD PERFOMANCE AND STABILITY OF DURUM WHEAT GENOTYPES IN MULTI ENVIRONMENT TRIALS IN ALGERIA
}

\author{
${ }^{1}$ Bendjama A., ${ }^{2}$ Solonechnyi P. \\ ${ }^{1}$ Technical Institute of Field Crops, Algeria \\ ${ }^{2}$ Plant Production Institute nd. a V.Ya. Yuriev NAAS, Ukraine
}

We evaluated the phenotypic stability and adaptability of durum wheat genotypes using the GGE (Genotype main effect (G) plus Genotype-Environment (GE) interaction) biplot model. The research was conducted in four locations by randomized complete block design with four replications in each location in during the 2008-09 and 2009-10 cropping seasons. The grain yields of all genotypes were significantly affected by environment, which accounted for $88.2 \%$ of the total variation, whereas genotype and genotype-environment interaction accounted for $2.9 \%$ and $8.9 \%$, respectively. GGE biplot reflected most of the variation caused by genotype and genotype-environment interaction effects in the first two principal components - 69.9\%. GGE biplot "which-won-where" showed that eight environments used for the study belonged to three megaenvironments with winning genotypes G20, G19 and G9. According to the ideal genotype biplot, genotypes G19, G20 and G12 were the best genotypes demonstrating high average yields and high stability of performance across the test locations. Based on the GGE biplot analysis, environment E4 (Kroub09/10) was the ideal test environment in terms of being the most representative of the overall environment and was chosen to select superior genotypes. Environments E2 (Guelma09/10) and E8 (Tiaret08/09) provide little or no information about the genotypic differences. The GGE biplot analysis permitted a meaningful and useful summary of GE interaction data and assisted in examining the natural relationships and variations in genotypes performance across the test locations.

Key words: GGE biplot, durum wheat, yield, adaptability, genotype-environment interaction, stability

Introduction. In dry areas, rainfed durum wheat yield is limited by biotic and abiotic stresses. Grain yield reductions were caused, mainly, by the combined effect of winter low temperatures, spring frosts, summer high temperatures and water shortage [1, 2]. Grain yield variations, ranging from as low as 1.8 to $3.6 \mathrm{t} / \mathrm{ha}$, at the same site in successive cropping seasons, were reported by Bahlouli et al. (2005) and Nouar et al. (2012) [3, 4] for durum wheat and by Kadi et al. (2010) and Meziani et al. (2011) for barley [5, 6]. Under such variable growth conditions, genotype x environments interaction is large enough to hinder selection progress, making prediction and genotype recommendation difficult. This is a particular problem where genotypes are tested and selected in one environment and targeted to other environments [7, 8]. Differential yield responses of genotypes can be caused by differences in phenology, growth habit, vernalization and/or photoperiodic responses [8]. In breeding programs, significant genotype $\mathrm{x}$ environment interaction can be ignored or properly exploited to advantage through various approaches [9].

Multi Environment Trials (METs) are important for studying yield stability, adaptation and as well for prediction of yield performance of genotypes across environments [10, 11]. Typically, environment causes most of the total yield variations, while genotype and genotypeenvironment interaction (GEI) are usually less effective [12, 13]. A large GEI variation usually hinders the accuracy of yield estimation and reduces correlation between genotypic and phenotypic values.

C) A. Bendjama, P. Solonechnyi. 2018.

ISSN 1026-9959. Селекція і насінництво. 2018. Випуск 114. 
GEI is a universal phenomenon when different genotypes are tested in a number of environments, and is an important issue for plant breeders and agronomists to predict cultivar behavior in different locations across different years prior to any recommendation concerning varieties [14-16]. In this context the joint regression and the additive main effects and multiplicative interaction (AMMI) models are helpful analytical tools $[17,18]$. These methods help understanding the magnitude of the interaction to be able to exploit its effects through appropriate selection strategies.

Yan et al. (2000) [19] proposed a modification of the conventional AMMI analysis called GGE (genotype and genotype-environment interaction), which is used for GEI analysis. The GGE analysis pools the genotype effect (G) with GE (multiplicative effect) and submits these effects to principal component analysis. According to Yan et al. (2000) [19], this biplot is identified as a GGE biplot. GGE biplot has some graphical visualization functions such as visualization of genotypes performance in a specific environment, visualization of relative adaptability of a genotype in a varying environment, visualization of comparison of two genotypes in different environments, visualization of identifying the best genotypes in each environment, visualization of an environmental group for a specific genotype(s), visualization of genotype average performance and stability, and visualization of discrimination and representation of environment [20].

This objective of our study was to evaluate the adaptability and yield stability of durum wheat genotypes using GGE biplot analysis to select genotypes that have both high performance and phenotypic stability.

Material and methods. The field trials were carried out during the 2008-09 and 20092010 cropping seasons at four locations in Algeria. The experimental sites characterized by a climate varying from subhumid to arid, are those of the experimental stations of the Technical Institute of Field Crops of Khroub (36 $\left.26^{\circ} \mathrm{N}, 06^{\circ} 66^{\prime} \mathrm{E}, 713 \mathrm{~m}\right)$, Sétif $\left(36^{\circ} 12^{\prime} \mathrm{N}, 05^{\circ} 24^{\prime} \mathrm{E}, 1023\right.$ $\mathrm{m})$, Guelma (36 $\left.45^{\prime} \mathrm{N}, 07^{\circ} 47^{\prime} \mathrm{E}, 272 \mathrm{~m}\right)$ and Tiaret $\left(36^{\circ} 05^{\prime} \mathrm{N}, 01^{\circ} 06^{\prime} \mathrm{E}, 1003 \mathrm{~m}\right)$ (Table 1).

Table 1

Weather conditions in the test sites

\begin{tabular}{|c|c|c|c|c|c|c|c|c|c|c|}
\hline \multirow[t]{2}{*}{$\begin{array}{l}\text { Cod } \\
\text { site } \\
\end{array}$} & \multicolumn{10}{|c|}{$\begin{array}{c}\text { Mean temperature }\left(\mathrm{C}^{\circ}\right) \\
2008 / 2009\end{array}$} \\
\hline & site & sep & oct & nov & dec & jan & feb & mar & apr & may \\
\hline E7 & Khroub & 21.7 & 16.9 & 10.3 & 6.8 & 7.1 & 6.5 & 9.4 & 10.9 & 17.7 \\
\hline E5 & Sétif & 21.0 & 15.2 & 8.2 & 4.9 & 5.2 & 4.8 & 8.1 & 9.1 & 17.1 \\
\hline E3 & Guelma & 24.9 & 20.8 & 14.3 & 10.7 & 11.1 & 12.3 & 13.3 & 16.5 & 18.1 \\
\hline \multirow[t]{3}{*}{ E8 } & Tiaret & 21.7 & 15.5 & 8.0 & 5.1 & 5.6 & 6.0 & 9.9 & 9.4 & 17.8 \\
\hline & \multicolumn{10}{|c|}{$2009 / 2010$} \\
\hline & site & sep & oct & nov & dec & jan & feb & mar & apr & may \\
\hline E4 & Khroub & 19.9 & 15.3 & 11.0 & 9.0 & 7.8 & 9.1 & 10.5 & 13.6 & 15.3 \\
\hline E1 & Sétif & 19.5 & 14.9 & 10.7 & 7.8 & 6.3 & 7.5 & 9.6 & 12.7 & 13.6 \\
\hline E2 & Guelma & 23.1 & 18.7 & 14.8 & 13.4 & 11.1 & 12.3 & 13.3 & 16.5 & 18.1 \\
\hline \multirow[t]{3}{*}{ E6 } & Tiaret & 19.5 & 16.4 & 12.2 & 9.4 & 7.6 & 8.9 & 10.3 & 13.0 & 14.8 \\
\hline & \multicolumn{10}{|c|}{$\begin{array}{c}\text { Average rainfall }(\mathrm{mm}) \\
2008 / 2009\end{array}$} \\
\hline & site & sep & oct & nov & dec & jan & feb & mar & apr & may \\
\hline E7 & Khroub & 38.8 & 21.0 & 37.6 & 27.0 & 76.4 & 48.6 & 81.1 & 113.3 & 43.4 \\
\hline E5 & Sétif & 45.2 & 55.5 & 23.0 & 38.3 & 66.6 & 38.3 & 31.6 & 79.4 & 5.0 \\
\hline E3 & Guelma & 29.7 & 25.4 & 70.6 & 35.8 & 160.4 & 67.4 & 98.0 & 134.2 & 88.9 \\
\hline \multirow[t]{3}{*}{ E8 } & Tiaret & 33.6 & 78.9 & 50.3 & 79.7 & 100.2 & 32.6 & 80.4 & 64.1 & 21.2 \\
\hline & \multicolumn{10}{|c|}{$2009 / 2010$} \\
\hline & site & sep & oct & nov & dec & jan & feb & mar & apr & may \\
\hline E4 & Khroub & 103.9 & 49.4 & 24.9 & 47.1 & 74.0 & 30.5 & 46.9 & 67.2 & 50.0 \\
\hline E1 & Sétif & 63.8 & 9.0 & 28.2 & 26.2 & 31.1 & 38.5 & 38.6 & 55.4 & 73.5 \\
\hline E2 & Guelma & 140.3 & 58.7 & 23.6 & 62.6 & 102.6 & 27.1 & 60.7 & 46.4 & 53.5 \\
\hline E6 & Tiaret & 90.4 & 11.4 & 51.0 & 79.9 & 57.4 & 138.6 & 66.6 & 14.6 & 38.9 \\
\hline
\end{tabular}


Twenty three durum wheat genotypes were tested, including commercial cultivars and advanced breeding lines from the national and Cimmyt-Icarda breeding programs (Table 2).

Table 2

Code and pedigree of 23 genotypes tested at the four locations during the 2008-09 and 200910 cropping seasons

\begin{tabular}{cl}
\hline Code & \multicolumn{1}{c}{ Pedigree } \\
\hline G1 & Hoggar check \\
G2 & MBB check \\
G3 & Boussellem check \\
G4 & Ter-2/3/HFN94-8/Mrb5/Zna-1 ICD00-1090-T-2AP-AP-2AP-TR \\
G5 & Mgnl3/Aghrass2 ICD99-0015-C-9AP-AP-21AP-AP \\
G6 & Adnan-1 ICD00-0866-C-0AP-5AP-AP-8AP-AP \\
G7 & Ter-1/Mrf1/Stj2 \\
G8 & Aghrass-1/HFN94N-8/Mrb5/Zna-1 ICD00-1085-T-2AP-AP-2AP-TR \\
G9 & Aghrass-1/3/Mrf1/Mrb16/Ru ICD00-0834-C-32AP-AP-6AP-TR \\
G10 & Amedakul-1 ICD96-0242-T-2AP-0AP-1AP-AP \\
G11 & Bigost-1 ICD96-0887-C-2AP-0AP-5AP-0AP \\
G12 & Mrf1/Stj2/Bcrch1 ICD99-0027-C-0AP-14AP-AP-9AP-AP \\
G13 & Aghrass-1/HFN94N-8/Mrb5/Zna-1 ICD00-1085-T-10AP-AP-10AP-AP \\
G14 & Stj2/Dra-2/Bcr/3/Ter-3 \\
G15 & Beltagy-2 ICD97-0396-T-1AP-AP-5AP-0AP-16AP-AP \\
G16 & Icasyr-1 ICD95-0169-C-0AP-3AP-0AP-5AP-0AP \\
G17 & Azeghar-2/Ch1/F1 13 ICD98-0493-W-AP-2AP-0AP-11AP-AP \\
G18 & Azeghar-1/Blm//Mrf-2 ICD00-0818-C-18AP-AP-9AP-TR \\
G19 & Miki-3 ICD94-0994-C-10AP-0AP-2AP-0AP-9AP-0TR \\
G20 & Azeghar-1/3/Mrf-2/Bcr/Gro-1 ICD00-0904-H-9AP-AP-1AP-TR \\
G21 & Ter-1/3/Stj3/Bcr/Lks-4 ICD99-1036-T-0AP-7AP-AP-3AP-AP \\
G22 & Ammar-2 ICD94-0918-C-12AP-0AP-6AP-0AP-3AP-0AP \\
G23 & Aghrass-1/3/HFN94N-8/Mrb5/Zna-1 ICD00-1065-T-4AP-AP \\
\hline
\end{tabular}

These genotypes were sown in a randomized complete block design in four replications. The experiments were conducted under rainfed conditions. Sowing was done in November with an experimental drill, in $1.2 \mathrm{~m}$ wide x $05 \mathrm{~m}$ long plots, at a seeding rate of $300 \mathrm{seeds} / \mathrm{m}^{2}$. The grain yields were determined by mechanical harvesting all 6 rows per plot.

ANOVA. Combined analysis of variance was performed for all the environments and included four locations and two cropping seasons. The treatment sum of squares was partitioned into its three components: genotype $(\mathrm{G})$, environment $(\mathrm{E})$ and genotype-environment interaction (GEI).

GGE biplot analysis. The GGE biplot methodology, which is composed of two concepts, the biplot concept [21] and the GGE concept [19], was used to visually analyze the multienvironment yield trials (METs) data. This methodology uses a biplot to show the factors (G and GE) that are important in genotype evaluation and that are also sources of variation in GEI analysis of METs data [12, 13].

The data on yields were mathematically processed using Genstat 12 software.

Results and discussion. Combined analysis of variance showed that there were highly significant differences for the environments, genotypes and their interactions. The results of combined analysis of variance are shown in Table 3. In our study, the durum wheat grain yields were significantly affected by the environment, which accounted for $88.2 \%$ of the total (G+E+GE) variation, whereas genotype and genotype-environment interaction accounted for $2.9 \%$ and 8.9 $\%$, respectively. A large sum of squares for environments indicated that the environments were diverse, with large differences between environmental means causing variation in the grain yields. In most multi-environment trials the environment accounts for over $80 \%$ of the total variation $[12,22,23]$. 
Table 3

Analyses of variance of the grain yield of 23 durum wheat genotypes in 8 environments

\begin{tabular}{lcccc}
\hline \multicolumn{1}{c}{ Source } & DF & SS & MS & G+E+GE SS (\%) \\
\hline Genotypes (G) & 22 & 55,3 & 2,51 & 2.9 \\
Environments (E) & 7 & 1640.9 & 234.41 & 88.2 \\
Block & 24 & 27.9 & 1.16 & \\
Interactions (GE) & 154 & 167.6 & 1.09 & 8.9 \\
Residuals & 54 & 18.4 & 0.34 & \\
Error & 528 & 288.5 & 0.55 & \\
Total & 735 & 2180.1 & 2.97 & \\
\hline
\end{tabular}

$\mathrm{DF}=$ degree of freedom; $\mathrm{SS}=$ sum of squares; $\mathrm{MS}=$ mean square

The mean performance of the tested genotypes across the testing years and locations ranged from 3.12 t/ha for G2 to 4.53 t/ha for G19 (Table 4). The mean yield of the testing environments varied from 1.73 t/ha for E8 (Tiaret 2008/09) to 6.55 t/ha for E7 (Khroub 2008/09), indicating the influence of soil, temperature, precipitation, etc. on yield.

Table 4

Mean grain yield $\left(\right.$ tha $\left.^{-1}\right)$ of 23 durum wheat genotypes in 8 environments

\begin{tabular}{cccccccccc}
\hline Genotype & E1 & E2 & E3 & E4 & E5 & E6 & E7 & E8 & Mean \\
\hline G1 & 3.4 & 2.9 & 5.3 & 5.6 & 3.4 & 3.0 & 6.2 & 1.7 & 3.925 \\
G2 & 3.1 & 2.3 & 4.8 & 2.9 & 2.5 & 4.0 & 3.6 & 1.8 & 3.121 \\
G3 & 5.0 & 2.9 & 5.2 & 5.8 & 3.3 & 3.9 & 6.7 & 2.0 & 4.338 \\
G4 & 3.4 & 3.0 & 4.2 & 4.6 & 3.2 & 3.1 & 6.6 & 1.8 & 3.747 \\
G5 & 3.4 & 2.8 & 5.3 & 6.0 & 3.5 & 3.3 & 7.2 & 1.6 & 4.149 \\
G6 & 3.7 & 2.5 & 4.9 & 5.8 & 3.6 & 4.1 & 7.1 & 1.3 & 4.123 \\
G7 & 3.8 & 2.7 & 4.6 & 5.3 & 3.6 & 2.9 & 7.1 & 1.5 & 3.934 \\
G8 & 3.3 & 3.2 & 5.1 & 5.2 & 3.4 & 3.2 & 6.2 & 1.8 & 3.911 \\
G9 & 2.7 & 2.2 & 5.2 & 6.3 & 3.8 & 3.5 & 7.6 & 1.9 & 4.149 \\
G10 & 4.0 & 2.8 & 5.6 & 5.5 & 3.9 & 2.9 & 6.6 & 1.8 & 4.152 \\
G11 & 4.1 & 2.8 & 4.3 & 6.1 & 3.5 & 2.9 & 6.9 & 1.6 & 4.030 \\
G12 & 3.6 & 2.9 & 5.7 & 6.5 & 3.7 & 3.6 & 7.1 & 1.5 & 4.333 \\
G13 & 3.7 & 2.7 & 5.0 & 5.7 & 3.5 & 3.0 & 7.1 & 1.7 & 4.039 \\
G14 & 3.7 & 2.2 & 4.9 & 5.7 & 3.6 & 3.2 & 6.0 & 1.8 & 3.888 \\
G15 & 3.9 & 2.9 & 4.8 & 6.0 & 3.5 & 3.6 & 6.8 & 1.4 & 4.114 \\
G16 & 3.7 & 2.5 & 4.9 & 5.5 & 3.5 & 3.8 & 7.4 & 2.0 & 4.174 \\
G17 & 4.2 & 2.5 & 3.6 & 6.1 & 3.2 & 3.7 & 6.9 & 2.2 & 4.030 \\
G18 & 4.0 & 2.4 & 5.5 & 5.7 & 3.2 & 4.6 & 6.6 & 1.7 & 4.208 \\
G19 & 4.6 & 3.3 & 4.9 & 7.1 & 3.9 & 4.0 & 6.6 & 1.9 & 4.526 \\
G20 & 4.3 & 2.6 & 5.8 & 6.2 & 3.9 & 3.3 & 7.1 & 1.7 & 4.358 \\
G21 & 4.7 & 2.2 & 6.1 & 5.7 & 3.8 & 4.6 & 5.6 & 1.7 & 4.282 \\
G22 & 4.1 & 2.8 & 4.5 & 6.3 & 3.3 & 2.8 & 7.0 & 1.7 & 4.069 \\
G23 & 3.7 & 2.2 & 5.1 & 5.8 & 3.6 & 3.3 & 4.7 & 1.8 & 3.766 \\
Mean & 3.838 & 2.666 & 4.999 & 5.708 & 3.495 & 3.490 & 6.547 & 1.733 & \\
\hline
\end{tabular}

According to Yan et al. (2007) [24], due to the discriminative ability and representativeness of GGE view, the biplot was an effective tool for environment evaluation, which was not possible with the AMMI model. In environment focusing scaled vector view of GGE biplot, the cosine of the angles between environment vectors shows relationships between test environments: with acute angles indicating strong positive correlation, obtuse angles - strong negative correlation or cross over GEI of genotypes, and right angle showing no correlation [25]. Hence, environment E5 highly correlated with E4, E2 - with E7 and E6 - with E3 (Figure 1).

Discriminating ability and representativeness of testing environments are an important measure in the GGE biplot. An environment is more desirable if it is located closer to the ideal environment. Thus, using the ideal environment as the centre, concentric circles were drawn to help visualize the distance between each environment and the ideal environment [26]. Figure 2 shows that 
environment E4 (Khroub09/10) was the ideal testing environment in terms of being the most representative of the overall environment and was chosen to select superior genotypes. Environments E2 (Guelma09/10) and E8 (Tiaret08/09), closer to the biplot origin, are characterized by similar performance of all genotypes; hence they provide little or no information about the genotypic differences, therefore, similar environments should not be considered as testing environments for yield trials. Environment E7 (Khroub08/09) has a long vector and a large angle with the abscissa, hence, should not be used for selecting superior genotypes, but useful for culling unsuitable genotypes.

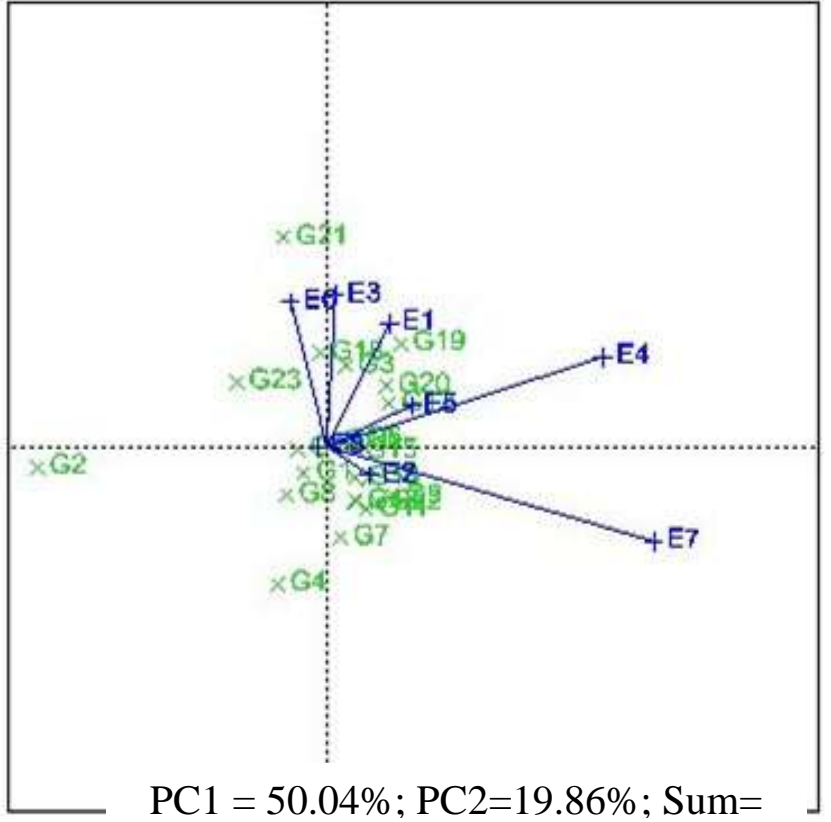

Figure 1. GGE biplot showing relationships among the test environments.

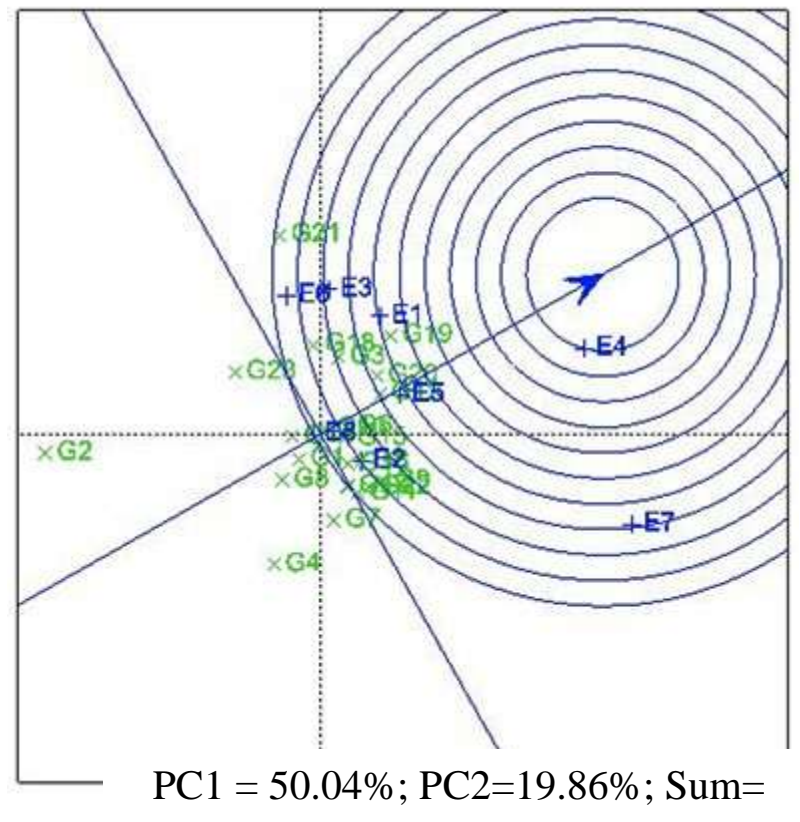

Figure 2. Ranking of environments based on discriminating ability and representativeness

Visualization of the "which-won-where" pattern of MET data is important for studying possible existence of different mega-environments (ME) in a region. The polygon view of a GGE biplot explicitly displays the "which-won-where" pattern and, hence, is a succinct summary of the GEI pattern of a MET data set (Figure 5). By connecting the genotype markers and the rays as depicted, the rays in Figure 3 are lines that are perpendicular to the sides of the polygon or their extensions. These rays divide the biplot into five sectors, but environments fall into three of them, so the genotypes vertex in these sectors may indicate higher or the highest yield compared to other parts in all environments.

Another important feature of this biplot is that it indicates environmental groupings, which suggests a possible existence of different mega-environments. Thus, in our studies the first mega-environment consists of environments E6, E3 and E1 with genotype G21 being the winner. The environments E5 and E4 makes up the second mega-environment, where genotype G19 is the winner. The last mega-environment consists of environments E2 and E7, where genotype G9 has the highest yield capacity.

The yield stability of genotypes was evaluated by the average environment coordination (AEC) method. In this method, the average principal components will be used in all environments, as depicted in Figure 4. A line is then drawn through this average environment and the biplot origin; this line is called the average environment axis and serves as the abscissa of the AEC. Unlike the AEC abscissa, having one direction, with the arrow pointing to a greater genotype main effect; the AEC ordinate in either direction away from the biplot origin indicates a greater GEI effect and reduced stability. The AEC ordinate separates genotypes with belowaverage means from those with above-average means. Genotypes G19, G3, G12, G20 and G21 had the highest mean yields, but yield of genotype G21 was the most variable, while genotypes G20 and G12 were noticeable for their high stability and productivity. 


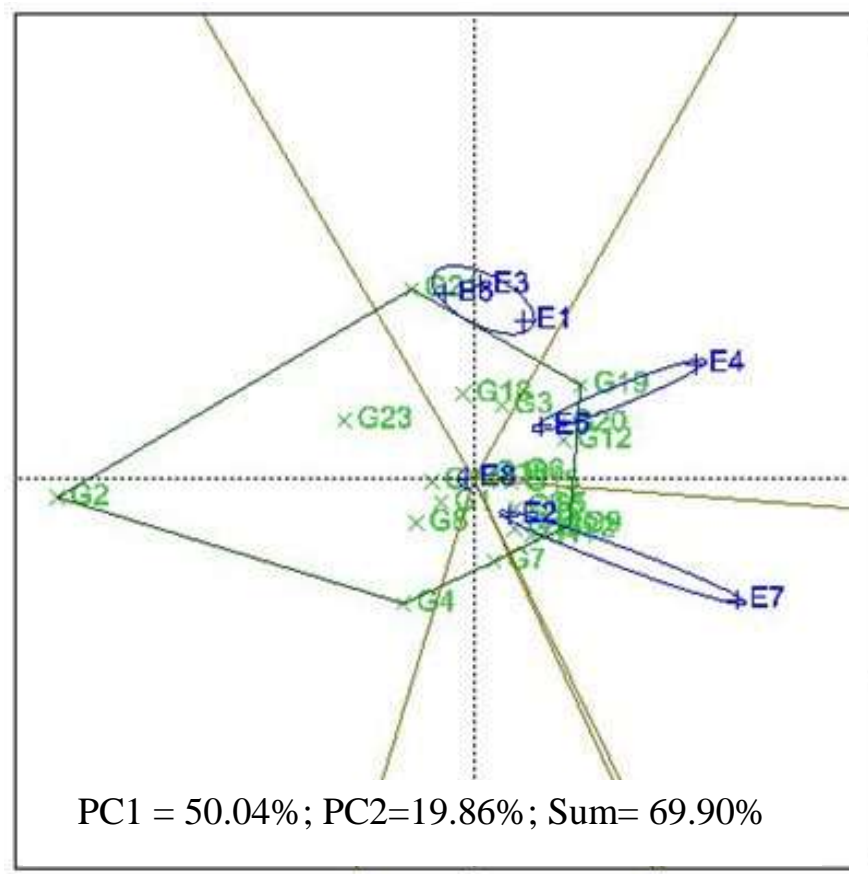

Figure 3. Polygon views of the GGE biplot based on symmetrical scaling for the «which-won where» pattern for genotypes and environments.

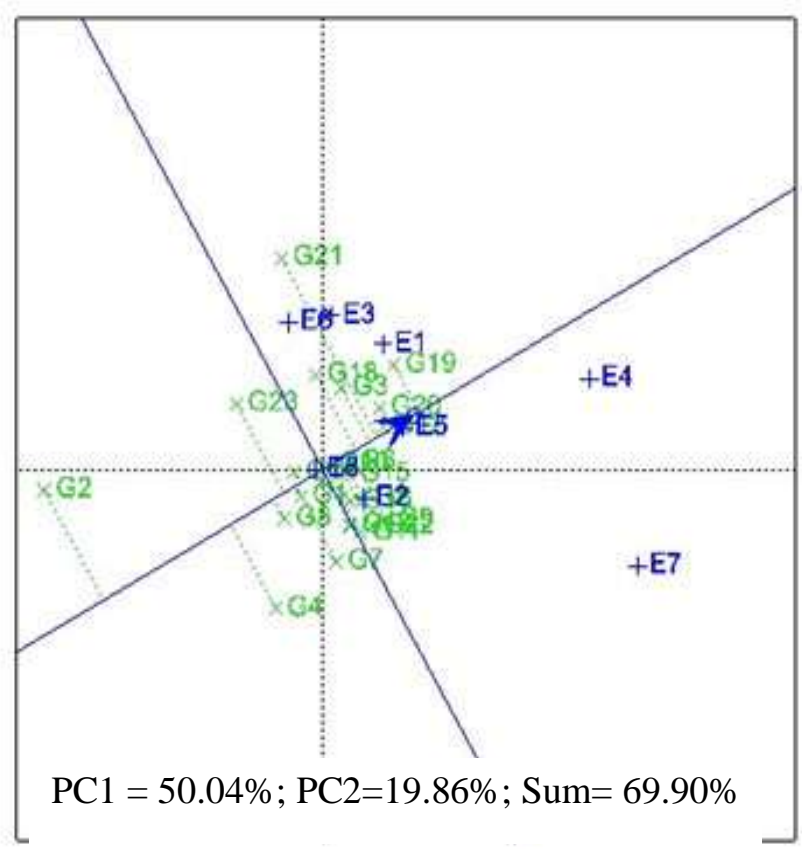

Figure 4. Average environment coordination (AEC) views of the GGE biplot based on environment-focused scaling for the mean performance and stability of genotypes

An "ideal" genotype is one that has both high mean yield capacity and high stability. The centre of concentric circles (Fig. 5) represents the position of an "ideal" genotype, which is defined by a projection onto the mean-environment axis that equals the longest vector of the genotypes that had above-average mean yields and by a zero projection onto the perpendicular line (zero variability across all environments). The closer a genotype to the ideal one is, the more valuable it is. Although such an "ideal" genotype may not exist in reality, it can be used as a reference for genotype evaluation [25].

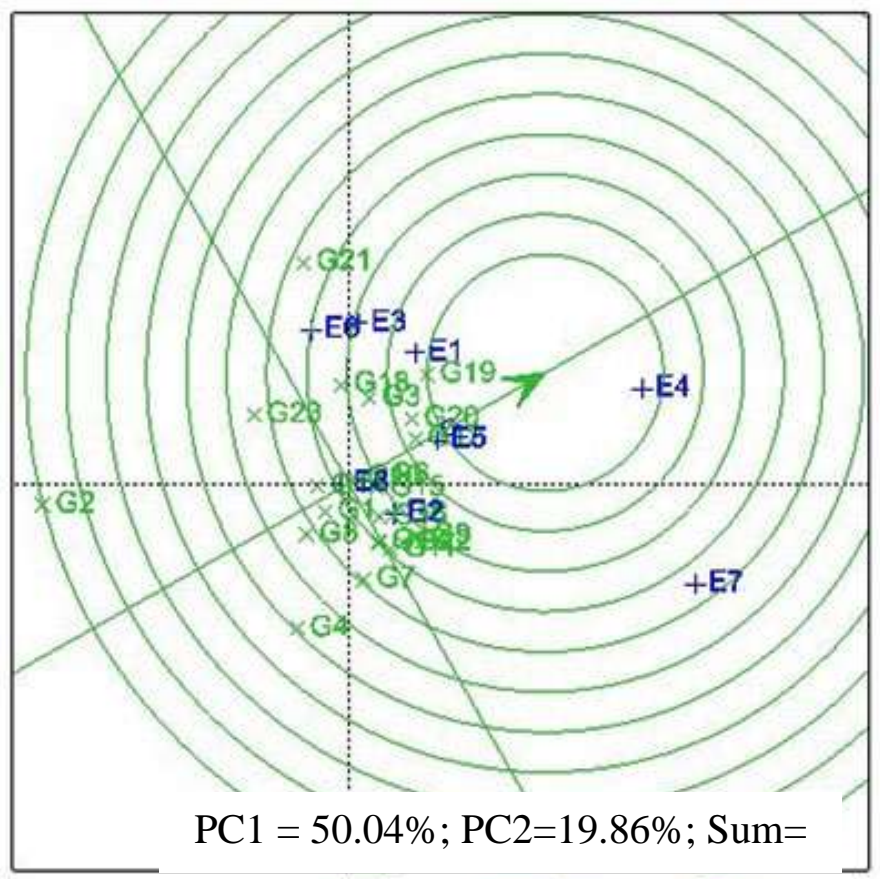

Figure 5. The average-environment coordination (AEC) view to rank genotypes relative to an ideal genotype 
The ranking based on the genotype-focused scaling assumes that stability and mean yield are equally important. Thus, genotypes G19, G12 and G 20, which are close to the centre of concentric circles, were "ideal" genotypes in terms of yield capacity and stability compared with the other genotypes.

Conclusion. The result ANOVA showed that the magnitude of the environmental effect was by far higher than the genotype effect and genotype-environment interaction effect. Durum wheat genotypes evaluated in this study had highly significant genetic differences in the grain yields across the environments.

The GGE biplot results indicated that yields of durum wheat genotypes were highly influenced by locations and growing season conditions. Genotypes G12, G19, G20 and G3 demonstrated best performance among the testing environments, while G2 had the lowest grain yield and adaptability. The study results distinguished genotype G19, which was the closest to the "ideal" genotype in terms of yield capacity and stability. Genotypes G12 and G20 were also remarkable for combination of yield capacity and stability.

GGE biplot analysis permitted a meaningful and useful summary of the GE interaction data and assisted in examining the natural relationships and variations in the genotypes performance across the test locations.

\section{References}

1. Annicchiarico P, Bellah F, Chiari T. Repeatable genotype $\mathrm{x}$ location interaction and its exploitation by conventional and GIS-based cultivar recommendation for durum wheat in Algeria. Eur. J. Agron. 2006; 24:70-81.

2. Chennafi H, Aidaoui A, Bouzerzour H, Saci A. Yield response of durum wheat (Triticum durum Desf.) cultivar Waha to deficit irrigation under semi arid growth conditions. Asian Journal of Plant Sciences Volume. 2006; 5(5): 854-860. DOI: 10.3923/ajps.2006.854.860.

3. Bahlouli F, Bouzerzour H, Benmahammed A. Hassous KL. Selection of high yielding and risk efficient durum wheat (Triticum durum Desf.) cultivars under semi-arid conditions. Pak. J. Agro. 2005; 4: 360-365. DOI: 10.1016/j.envexpbot.2011.05.002.

4. Nouar H, Bouzerzour H, Haddad L, Menad A. Genotype x environment interaction assessment in durum wheat (Triticum durum Desf.) using AMMI and GGE models. Adv. Environ. Biol. 2012; 6: 3007-3015.

5. Kadi Z, Adjel F, Bouzerzour H. Analysis of the Genotype X Environment interaction of barley grain yield (Hordeum vulgare L.) under semi arid conditions. Adv. Environ. Biol. 2010; 4(1): 34-40.

6. Meziani NH, Bouzerzour A, Benmahammed A et al. Performance and adaptation of barley genotypes (Hordeum vulgare L.) to diverse locations. Adv. Environ. Biol. 2011; 5: 14651465.

7. Farshadfar E, Sutka J. Multivariate analysis of drought tolerance in wheat substitution lines. Cereal Research Communications. 2003; 31(1-2): 33-40.

8. Oosteroom EJ, Ceccarelli S, Peacock JM. Yield response of barley to rainfall and temperature in Mediterranean environments. The Journal of Agricultural Science. 1993; 121(03): 307-313. DOI: 10.1017/S0021859600085488.

9. Annicchiarico P, Pecetti L, Abdelguerfi A, Bouizgaren A, Carroni AM, Hayek T, Hammadi Bouzina MM, Mezni M. Adaptation of landrace and variety germplasm and selection strategies for lucerne in the Mediterranean basin. Field Crops Res. 2011; 120: 283-291. DOI: 10.1016/j.fcr.2010.11.003.

10. Solonechnyi P, Vasko N, Naumov O, Solonechnaya O, Vazhenina O, Bondareva O, Logvinenko Yu. GGE biplot analysis of genotype by environment interaction of spring barley varieties. Zemdirbyste-Agriculture. 2015; 102(4): 431-436. DOI: 10.13080/z-a.2015.102.055. 
11. Solonechnyi P, Kozachenko M, Vasko N et al. AMMI and GGE biplot analysis of yield performance of spring barley (Hordeum vulgare L.) varieties in multi environment trials. Agriculture \& Forestry. 2018; 64(1): 121-132. DOI: 10.17707/AgricultForest. 64.1.15

12. Yan W, Kang MS. GGE biplot analysis: a graphical tool for breeders, geneticists and agronomists. Boca Raton, USA. 2003.

13. Dehghani H, Sabaghpour SH, Ebadi-Segherioo A. Study of genotype $\times$ environment interaction for chickpea yield in Iran. Agronomy Journal. 2010; 102: 1-8.

14. Annicchiarico P. Genotypexenvironment interactions: challenges and opportunities for plant breeding and cultivar recommendations. FAO Plant Production and Protection Paper. FAO, Rome. 2002. P. 174.

15. Karimizadeh R, Mohammadi M, Shefazadeh MK, Karimpour F. Relationship among and repeatability of ten stability indices for grain yield of food lentil genotypes in Iran. Turkish J. Field Crop. 2012; 17(1): 51-61.

16. Mortazavian SMM, Nikkhah HR, Hassani FA, Sharif-al-Hosseini M, Taheri M, Mahlooji M. GGE biplot and AMMI analysis of yield performance of barley genotypes across different environments in Iran. J. Agr. Sci. Tech. 2014; 16: 609-622.

17. Finlay KW, Wilkinson GN. The analysis of adaptation in a plant-breeding programme. Australian Journal of Agricultural Research. 1963; 14: 742-754. DOI: 10.1071/AR9630742.

18. Zobel RW, Wright AJ, Gauch HG. Statistical analysis of a yield trial. Agronomy Journal. 1988; 80: 388-393. DOI: 10.2134/agronj1988.00021962008000030002x.

19. Yan W, Hunt LA, Sheny Q, Szlavnics Z. Cultivar evaluation and mega-environment investigation based on the GGE biplot. Crop Science. 2000; 40: 597-605. DOI: 10.2135/cropsci2000.403597x.

20. Yan W, Hunt LA. Interpretation of genotype - environment interaction for winter wheat yield in Ontario. Crop Science. 2001; 41: 19-25.

21. Gabriel KR. The biplot graphic display of matrices with application to principal component analysis. Biometrika. 1971; 58(3): 453-467. DOI: 10.2307/2334381.

22. Yan W. Singular-value partitioning in biplot analysis of multi-environment trial data. Agronomy Journal. 2002; 94: 990-996. DOI: 10.2134/agronj2002.9900.

23. Gauch HGJr, Piepho PH, Annicchiarico P. Statistical analysis of yield trials by AMMI and GGE: further considerations. Crop Science. 2008; 48: 866-889. DOI: 10.2135/cropsci2007.09.0513.

24. Yan W, Kang MS, Ma B, Woods S. GGE biplot vs. AMMI analysis of genotype by environment data. Crop Science. 2007; 47: 643-655. DOI: 10.2135/cropsci2006.06.0374.

25. Yan W, Tinker NA. Biplot analysis of multi-environment trial data: principles and applications. Can. J. Plant Sci. 2006; 86: 623-645. DOI: 10.4141/P05-169.

26. Yan W, Rajcan I. Biplot evaluation of test sites and trait relations of soybean in Ontario. Crop Science. 2002; 42: 11-20.

\title{
GGE ВIPLOT АНАЛІЗ УРОЖАЙНОСТІ ТА СТАБІЛЬНОСТІ ГЕНОТИПІВ ПШЕНИЦІ ТВЕРДОЇ В ЕКОЛОГІЧНОМУ СОРТОВИПРОБУВАННІ У АЛЖИРІ
}

\author{
${ }^{1}$ Бенджама А., ${ }^{2}$ Солонечний П. \\ ${ }^{1}$ Технічний інститут польових культур, Алжир \\ ${ }^{2}$ Інститут рослинництва ім. В.Я. Юр'єва НААН, Україна
}

Вступ. У посушливих умовах Алжиру врожайний потенціал сортів пшениці твердої реалізується не повною мірою. За таких несприятливих умов добір кращих генотипів $\epsilon$ ускладненим, особливо якщо вони оцінюються лише в одному середовищі. Тому для більш ефективної оцінки продуктивності та адаптивного потенціалу перспективних генотипів було проведено екологічне сортовипробування на чотирьох експериментальних станціях Технічного інституту польових культур (Алжир). 
Метою даного дослідження було оцінити врожайність та стабільність генотипів твердої пшениці з використанням GGE біплот аналізу для добору генотипів з високою продуктивністю та фенотиповою стабільністю.

Матеріали та методи. Дослідження проведено у 2008-09 та 2009-10 роках у чотирьох пунктах випробування 3 повною рандомізацією з чотирма повтореннями. За вихідний матеріал було використано 23 генотипи твердої пшениці - комерційні сорти та селекційні лінії від національних та CIMMYT-ICARDA селекційних програм.

Обговорення результатів. На врожайність усіх генотипів значно вплинули умови вирощування, цей фактор обумовлював 88,2 \% від загальної дисперсії врожайності, тоді як вплив генотипу та взаємодія між генотипом та середовищем становила 2,9 \% та 8,9\% відповідно. GGE біплот відображав більшу частину варіації, викликану ефектами взаємодії генотипу та генотипу-середовища в перших двох основних компонентах $-69,9 \%$. GGE біплот "який генотип де виграє" показав, що вісім досліджених середовищ сформували три мега-середовища, в яких найбільш продуктивними були генотипи G20, G19 і G9. Генотипи G19, G3, G12, G20 та G21 мали найбільшу середню врожайність. При цьому врожайність генотипу G21 була найбільш варіабельною, тоді як генотипи G20 i G12 характеризувалися високою та стабільною продуктивністю. Порівняння 3 «ідеальним» генотипом виявило, що найкращими за поєднанням високої врожайності та іiі стабільного прояву були генотипи G19, G20 і G12. Аналіз диференціюючої здатності та репрезентативності середовищ виявив, що середовище E4 (Khroub09/10) було ідеальним для тестування генотипів, так як воно було найбільш інформативним та репрезентативним, тобто $є$ оптимальним для вибору кращих генотипів. Середовища E2 (Guelma 09/10) та E8 (Tiaret 08/09) були не інформативними щодо диференціації генотипів.

Висновки. Детально оцінено взаємодію генотип-середовище за допомогою GGE біплот аналізу, що дозволило добрати найбільш продуктивні та стабільні генотипи, а також генотипи $з$ широкою та специфічною адаптивністю.

Ключові слова: GGE біплот, пшениия тверда, врожайність, адаптивність, взаємодія генотип-середовище, стабільність

\section{GGE ВIPLOT АНАЛИЗ УРОЖАЙНОСТИ И СТАБИЛЬНОСТИ ГЕНОТИПОВ ПШЕНИЦЫ ТВЕРДОЙ В ЭКОЛОГИЧЕСКОМ СОРТОИСПЫТАНИИ В АЛЖИРЕ}

${ }^{1}$ Бенджама А., ${ }^{2}$ Солонечный П.

${ }^{1}$ Технический институт полевых культур, Алжир

${ }^{2}$ Институт растениеводства им. В.Я. Юрьева НААН, Украина

Введение. В засушливых условиях Алжира урожайный потенциал сортов пшеницы твердой реализуется не полной мерой. При таких неблагоприятных условиях отбор лучших генотипов усложнен, особенно если они оцениваются только в одной среде. Поэтому для более эффективной оценки продуктивности и адаптивного потенциала перспективных генотипов было проведено экологическое сортоиспытание на четырех экспериментальных станциях Технического института полевых культур (Алжир).

Целью данного исследования была оценка урожайности и стабильность генотипов твердой пшеницы с использованием GGE биплот анализа для отбора генотипов с высокой продуктивностью и фенотипической стабильностью.

Материалы и методы. Исследования проведены в 2008-09 и 2009-10 годах в четырех пунктах испытания с полной рандомизацией с четырьмя повторениями. Исходным материалом были 23 генотипа твердой пшеницы - коммерческие сорта и селекционные линии из национальных и CIMMYT-ICARDA селекционных программ.

Обсуждение результатов. На урожайность всех генотипов значительно повлияли условия выращивания, этот фактор обуславливал 88,2 \% от общей дисперсии урожайности, тогда как влияние генотипа и взаимодействия между генотипом и средой составляло 2,9 \% 
и $8,9 \%$ соответственно. GGE биплот отображал большую часть вариации, вызванную эффектами взаимодействия генотипа и генотипа-среды в первых двух основных компонентах - 69,9 \%. GGE биплот "какой генотип где выигрывает" показал, что восемь исследованных сред сформировали три мега-среды, в которых наиболее продуктивными были генотипы G20, G19 и G9. Генотипы G19, G3, G12, G20 и G21 характеризовались наибольшей средней урожайностью. При этом урожайность генотипа G21 была наиболее вариабельна, тогда как генотипы G20 и G12 характеризовались высокой и стабильной продуктивностью. Сравнение с «идеальным» генотипом показало, что лучшими по уровню урожайности и его стабильного проявления были генотипы G19, G20 и G12. Анализ дифференцирующей способности и репрезентативности сред показал, что среда E4 (Khroub09/10) была идеальной для тестирования генотипов. Эта среда была наиболее информативной и репрезентативной, то есть она является оптимальной для отбора лучших генотипов. Среды E2 (Guelma 09/10) и E8 (Tiaret 08/09) были не информативными относительно дифференциации генотипов.

Выводы. Детально оценено взаимодействие генотип-среда при помощи GGE биплот анализа, что позволило отобрать наиболее продуктивные и стабильные генотипы, а также генотипы с широкой и специфической адаптивностью.

Ключевые слова: GGE биплот, пшенииа твердая, урожайность, адаптивность, взаимодействие генотип-среда, стабильность

\title{
GGE BIPLOT ANALYSIS OF YIELD PERFOMANCE AND STABILITY OF DURUM WHEAT GENOTYPES IN MULTI ENVIRONMENT TRIALS IN ALGERIA
}

\author{
${ }^{1}$ Bendjama A., ${ }^{2}$ Solonechnyi P. \\ ${ }^{1}$ Technical Institute of Field Crops, Algeria \\ ${ }^{2}$ Plant Production Institute nd. a V.Ya. Yuriev NAAS, Ukraine
}

Introduction. In the arid conditions of Algeria, the productive potential of durum wheat varieties is not fully fulfilled. Under such unfavorable conditions, selection of the best genotypes is complicated, especially if they are evaluated only in one environment. Therefore, for a more effective assessment of the performance and adaptive potential of promising genotypes, an environmental variety trial was conducted at four experimental stations of the Technical Institute of Field Crops (Algeria).

The purpose of this study was to evaluate the yield and stability of durum wheat genotypes using the GGE biplot analysis to select genotypes with a high performance and phenotypic stability.

Materials and Methods. The study was conducted in four testing sites with full randomization in four replicas in 2008-09 and 2009-10. Twenty durum wheat genotypes, commercial varieties and breeding lines from national and CIMMYT-ICARDA breeding programs were taken as the test material.

Results and Discussion. The yields of all the genotypes were significantly influenced by the growing conditions; this factor accounted for $88.2 \%$ of the total variance of yield, while the genotype effect and the genotype-environment interaction effect accounted for $2.9 \%$ and $8.9 \%$, respectively. The GGE biplot represented most of the variation caused by the effects of genotype and the genotype-environment interaction in the first two principal components $69.9 \%$. The "which-won-where" GGE biplot showed that the 8 environments under investigation formed 3 mega-environments in which genotypes G20, G19 and G9 were the most productive. Genotypes G19, G3, G12, G20, and G21 gave the highest average yields. The yield of genotype G21 was the most variable, whereas genotypes G20 and G12 had high and stable performance. Comparison with the "ideal" genotype showed that genotypes G19, G20 and G12 were the best in terms of yield and its stability. Analysis of the differentiating ability and representativeness of the environments demonstrated that environment E4 (Khroub09/10) was ideal for testing genotypes. This environment was the most informative and representative, 
that is, it is optimal for selecting the best genotypes. Environments E2 (Guelma 09/10) and E8 (Tiaret 08/09) were not informative regarding differentiation of genotypes.

Conclusions. The genotype-environment interaction was evaluated in detail using the GGE blot analysis, which allowed selecting the most productive and stable genotypes, as well as genotypes with broad and specific adaptability.

Key words: GGE biplot, durum wheat, yield, adaptability, genotype-environment interaction, stability

\section{СТВОРЕННЯ СЕЛЕКЦИИНОГО МАТЕРІАЛУ ГОРОХУ З ПІДВИЩЕНОЮ ЯКІСТЮ НАСІННЯ}

Василенко А.О., Безуглий І.М., Шевченко Л.М., Штельма А.М., Глянцев А.В., Шелякіна Т.А. Інститут рослинництва ім. В.Я. Юр'єва НААН, Україна

Представлено результати створення вихідного матеріалу гороху методом бекросу і випробування отриманого селекційного матеріалу впродовж 2013-2018 рр. Аналіз головних господарських ознак створеного матеріалу - врожайності і вмісту білка підтвердив донорські властивості сортів Харківський янтарний і Банан. Зроблено висновок, що для підвищення ефективності селекційного процесу необхідно використовувати донори за певними господарськими ознаками.

Ключові слова: горох, селекція, урожайність, вміст білка, бекрос, донор

Вступ. На теперішній час до класичних методів створення вихідного матеріалу в селекції рослин (гібридизації, мутагенезу та ін.) додались біотехнологічні (культура пиляків, та ін.) та молекулярні (трансгенез, та ін.). Але вибір методу схрещування та батьківських компонентів для схрещування і досі залишається грунтовною проблемою.

Аналіз літературних джерел, постановка проблеми. Відповідним чином проведена оцінка внутрішньовидового різноманіття сільськогосподарських рослин, що сконцентровано у генбанках світу, може забезпечити вирішення багатьох традиційних і нових проблем в селекції, а також виявити і створити вихідний матеріал для вирішення будь-якої проблеми з якою може зіштовхнутися селекціонери [1].

Селекція шляхом гібридизації має більше шансів на успіх, якщо буде виконано наступні умови: по-перше, визначено чітку мету, по-друге, підібрано батьківські компоненти, що відповідають меті, по-третє, застосовано відповідні методи гібридизації і, четверте, гібридні популяції опрацьовано відповідними методами [2].

Використання в якості батьківських компонентів комерційних сортів є виправданим, так як уже створений генотип пройшов значний шлях від схрещування до визнання в якості сорту, тобто має велику перевагу перед іншими. В той же час такі схрещування можуть призвести до генетичної вразливості [1]. За даними Вишняковой М.А. та ін. серед колекції гороху ВИР середземноморські зразки представлено головним чином комерційними сортами - з наявних 685 зразків 268 сортів надійшло з Франції як одного з світових лідерів виробництва гороху [3]. В Національному центрі генетичних ресурсів рослин України у базовій колекції генофонду виду Pisum sativum L., яка на 01.01.2014 р. налічує 2662 зразків, переважну частину (1527 зразків) становлять селекційні сорти, з яких 222 - вітчизняної селекції різних років[4].

(C) A. Bendjama, P. Solonechnyi. 2018.

ISSN 1026-9959. Селекція і насінництво. 2018. Випуск 114. 